REFLECTIONS:

NEUROLOGY AND THE

HUMANITIES

Section Editor

Michael H. Brooke, MD

\title{
Reflections for May
}

Nina F. Schor, MD, PhD VACATION

Address correspondence and reprint requests to Dr. Nina F. Schor, Golisano Children's

Hospital of URMC, 601 Elmwood Ave., Box 777, Rochester, NY 14642 nina_schor@urmc.rochester.edu

\section{Vacation I}

Mountain,
I cannot tell just

Looking at you,

If you wake each day

Hearing Greek or Italian or Turkish.

And the wave I follow

From ship's bow to shore's end

Hits sand that calls itself

Only "Earth."

How petty, how arbitrary

The lines we draw between cultures.

And how freely we share now

At sea.

\section{Vacation II}

"My brain just does not do 'relax'

"As well as I would like it to,"

She said. I will need to push myself

To practice.

Quite satisfied was she in this

Certain defeat of purpose.

\section{Vacation III}

Some of what has accumulated has

Taken care of itself.

Some of what has accumulated has

Developed further than the first communication would indicate.

Some of what has accumulated

Wasn't worth the energy needed to hit "Delete."

Some of what has not accumulated has made me proud

That the sometimes shaky orchestra has learned to play in counterpoint

Without a conductor.

Lead well,

And you shall be deserted

By those who become your most worthy

Successors.

\section{FAMILY LIFE}

\section{For My Father}

You lived in a self-made cage.

And, like everything you made,

It was beautiful.

Gilded, unique, perfect.

The unfortunate product of

Only "of mine" is worth knowing

And needing "of others" is weakness.

Its beauty made people say,

'How wonderful that you have this outlet for your talents.'

But like all cages,

It had no outlet.

So you decorated and decorated and decorated it From within

Until the wall space and your passion

Ran out.

\section{For My Mother}

You and I made them laugh.

We were the joke.

It was not funny.

But it was rewarding.

We even made each other laugh.

Now that was funny.

\section{Social Economics}

It is not easy

Living in a Marxist family

(From each according to his ability,

To each according to his need)

If they have all the need

And you have all the ability.

But they are all that is left

When the evening descends

And the silence envelops the dark. 


\title{
Neurology
}

\author{
Reflections for May \\ Nina F. Schor \\ Neurology 2010;74;1552
}

DOI 10.1212/WNL.0b013e3181dd41fb

\section{This information is current as of May 10, 2010}

\section{Updated Information \& Services}

Subspecialty Collections

Permissions \& Licensing

\section{Reprints}

including high resolution figures, can be found at: http://n.neurology.org/content/74/19/1552.full

This article, along with others on similar topics, appears in the following collection(s):

\section{Other Education}

http://n.neurology.org/cgi/collection/other_education

Professional conduct and ethics

http://n.neurology.org/cgi/collection/professional_conduct_and_ethics

Information about reproducing this article in parts (figures,tables) or in its entirety can be found online at:

http://www.neurology.org/about/about_the_journal\#permissions

Information about ordering reprints can be found online:

http://n.neurology.org/subscribers/advertise

Neurology ${ }^{\circledR}$ is the official journal of the American Academy of Neurology. Published continuously since 1951, it is now a weekly with 48 issues per year. Copyright. All rights reserved. Print ISSN: 0028-3878. Online ISSN: 1526-632X.

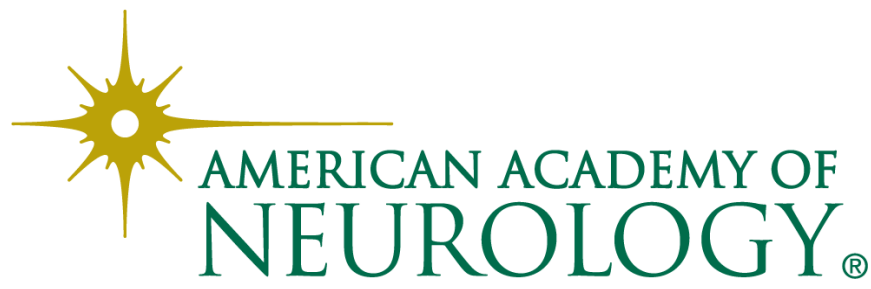

